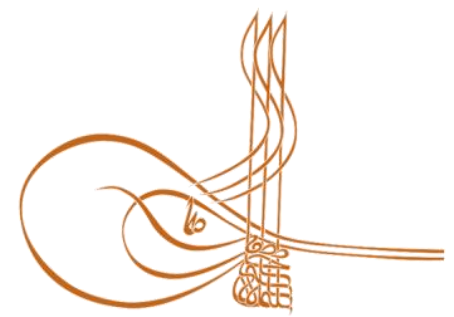

www.turkishstudies.net/economy
Turkish Studies - Economics, Finance, Politics

eISSN: $2667-5625$

Research Article / Araşttrma Makalesi

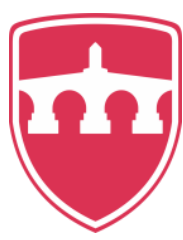

INTERNATIONAL BALKAN

UNIVERSITY

Sponsored by IBU

\title{
Muhasebe Eğitimi Alan Öğrencilerin Eğitim Hizmet Kalitesi Değerlendirmeleri Üzerine Bir Araştırma
}

\author{
Research in the Quality of Education Service Students of Accounting Education
}

\author{
Filiz Aslan Çetin ${ }^{*}$ Seyhan Öztürk ${ }^{* *}$
}

\begin{abstract}
In today's conditions, the issue that needs to be emphasized in educational institutions is the quality of the education service provided. In this context, it is possible to provide service quality with a human-oriented thinking. Therefore, in this study, it has been mentioned how the perception of the elements of the service quality of the education of the university students who have received accounting education in general and a survey study has been conducted in Kafkas University Faculty of Economics and Administrative Sciences. Undoubtedly, the main consumer group of the people who provide education services are the students who want to get that education. The understanding of quality in service has been created in order to make consumer satisfaction permanent and to ensure that this satisfaction is sustainable. Therefore, it is important to learn from these students what the quality elements are and how this affects the faculty in which they are involved. In this context, a questionnaire was applied to 123 students who have studied accounting at Kafkas University Faculty of Economics and Administrative Sciences. Fourth grade students from the department of business administration, economics and political science and public administration were included in the research group. Five sub-dimensions of service quality in the study; accounting training, customer focus, respect, physical conditions and security, as well as organizational skills and transport elements were examined. Factor analysis was performed by examining each service subdimension according to the demographic characteristics of the students. According to this, while there was a significant difference in terms of gender and department, there was no significant difference according to age groups.
\end{abstract}

Structured Abstract: In recent years, it is obvious that service is indispensable for all institutions. The share of services, especially in developed countries, is gradually increasing among the dynamics of national economies. On the one hand, this increase in the service sector has become an indicator of development and

\footnotetext{
${ }^{*}$ Dr. Öğr. Üyesi, Kafkas Üniversitesi, İktisadi ve İdari Bilimler Fakültesi, İşletme Bölümü Asst. Prof. Dr., Kafkas University, Faculty of Economics and Administrative Sciences, Department Of Business ORCID 0000-0002-8210-799X

filizaslan79@gmail.com

** Doç. Dr., Kafkas Üniversitesi, İktisadi ve İdari Bilimler Fakültesi, İşletme Bölümü Assoc.Prof., Kafkas University, Faculty of Economics and Administrative Sciences, Department Of Business ORCID 0000-0003-1458-840X

seyhan87ozturk@gmail.com

Cite as/ Atıf: Aslan Çetin, F. \& Öztürk, S. (2020). Muhasebe eğitimi alan öğrencilerin eğitim hizmet kalitesi değerlendirmeleri üzerine bir araştırma, Turkish Studies - Economy, Finance, Politics, 15(1), 35-52. https://dx.doi.org/10.29228/TurkishStudies.39384

Received/Geliş: 19 October/Ekim 2019

Accepted/Kabul: $25 \mathrm{March} /$ Mart 2020

Copyright $(\mathcal{C}$ INTAC LTD, Turkey

Checked by plagiarism software

Published/Yayın: 30 March/Mart 2020

CC BY-NC 4.0
} 
high living standards. On the other hand, it can be said that activities are lacking when there is no service and therefore service is a sine qua non.

In this context, the service sector has an expanding range. It is necessary to adapt services to many areas such as transportation, entertainment, food and beverage, accommodation, finance, insurance, communication and education. Especially considering the compelling effect of the fierce competition environment in the global world, it has become a necessity for educational institutions to come to the forefront not only with service but also with quality service. Many programs have been developed in order to create the elements of the necessary service in the educational institutions and to emphasize the quality so that the control of both the production and consumption stages of the information that is the output of the educational service will be provided and the quality will be spread to all areas.

Considering all these, the study starts with a theoretical framework consisting of quality, service, service quality and measurement of service quality and the quality of accounting education.

First of all, quality is defined as bringing together various processes of development activities in the organization. In fact, quality; It is also defined as a judgment or attitude that approves the superiority of the service that any person receives. Service is defined as an economic activity that results from a change in value between the two parties in the market environment. Providing a systematic service is one of the biggest problems of the institutions and they have to create many different strategies for this. Institutions have now recognized the link between quality of service and sustainability. Because the concept of service quality is important for both the service provider and the service provider.

Although there are many methods that measure service quality in the literature, SERVQUAL (Service Quality) is the most widely used method. SERVQUAL method was developed in 1985 and started to be used. In this method, there are five criteria that define the quality of service received by consumers regardless of the type of service; physical elements, reliability, sensitivity, precision and empathy.

Another concept in the study is education. Education; It is a long-term process in which the individual develops his / her abilities, attitudes and behaviors in the society in which he / she is a member. In this process, the individual develops his / her personality through education, increases his / her knowledge and skills, and acquires a profession according to his / her interests and abilities. In this context, vocational training; To gain knowledge, skills and attitudes required by a particular occupation is all of its education to develop it in various aspects. Accounting education provides the professional knowledge and ethics that people should have in the field of accounting. Accounting science is a field of application which is very high, so it can only be realized by increasing the quality of accounting education by supporting the basic accounting knowledge with real practices while presenting to the student.

In the application part of the study, the questionnaire which includes demographic questions and expressions is presented to the participants and the findings are obtained and subjected to analysis to reach the results. The data obtained were evaluated with SPSS 21 program. The field of application is the fourth grade students of Kafkas University, Faculty of Economics and Administrative Sciences. In this context, the main purpose of the research; The aim of this course is to determine the quality assessment of accounting education, which is seen as the basic course in each department, and to evaluate the university in which students belong to in the context of the service they receive. In addition, in the service quality evaluations, especially which service quality dimensions they give importance to are examined in the study.

The descriptive research model was used in this field research, which aims to determine the evaluation of accounting education service in terms of quality by the students in the context of the service they provide in general and the students of the Faculty of Economics and Administrative Sciences. The main population (universe) of this study, which is included in the field study, is composed of students who have studied accounting at the Faculty of Economics and Administrative Sciences, and who are able to graduate. The aim here is; the students have spent a certain period of time in the university and have taken different accounting courses in particular, and the statements in the questionnaire provide an opportunity to evaluate accounting education in terms of quality. Participants who graduated voluntarily from the 4th grade students voluntarily accepted to fill the questionnaire constitute the main body and the main body is approximately 153 people. According to the sample calculation program, the number of samples that is sufficient to reach $95 \%$ confidence interval is 110 and 122 questionnaires were found to be worth analyzing from 153 questionnaires

Turkish Studies - Economy, 15(1) 
due to the fact that the application had limited time, space and especially the scarcity of students and some of the questionnaires were worthless.

The questionnaire used in the research consists of two parts. In the first part of the survey, 5 questions about the demographic characteristics of the students, in the second part; accounting courses, customer focus, respect, physical status and trust, organizational skills and transportation. In order to analyze the demographic characteristics of the participants, descriptive statistics were explained as frequency and percentage. In addition, "factor analysis" was conducted in order to determine which factors affect service quality evaluations. Kruskal Wallis-H test was used to test hypotheses.

When the demographic characteristics of the participants are examined, it is seen that the majority of the participants are male and 21-25 years old, have studied business administration and have graduated from Anatolian High School before university education. When the factor analysis results are analyzed, the first factor is named as eğitim accounting education olup and it consists of six statements aimed at evaluating the accounting education service in particular. The second factor is named as "customer focus; It consists of five expressions. The third factor; It is called "respect olup and consists of four expressions. The fourth factor is named as koşullar physical conditions and trust, and consists of seven expressions in this sense. The fifth and last factor is called "organizational skill and transportation ve and consists of seven statements.

In addition, analyzes were conducted to test the hypotheses created within the study. Accordingly, in the first hypothesis, the mean scores obtained from the variation of participation in each dimension average of the students participating in the research according to gender; female participants were higher for each dimension. In the second hypothesis, the mean scores obtained from the variation of the participation in each dimension average of the students participating in the research according to the chapters read by the students; it was found to be higher for the students attending the department of social sciences (political science and public administration) for each dimension. In the third hypothesis, the mean scores obtained from the variation of participation in each dimension average of the students participating in the research according to age groups; for each dimension, it was found to be higher in the participants under 20 years of age. However, there is no significant difference between the mean quality of service sub-dimensions according to age groups of the participating students.

As a result; The answers given to the statements provided within the scope of service quality have been concentrated in five sub-factors such as "accounting training", "customer focus", "respect", "physical conditions and trust", "organizational skills and transportation". All of these factors should be taken into consideration by educational institutions and it should be taken into consideration that they address a young audience.

Keywords: Service, Quality of Service, Accounting Education.

Öz: Günümüz koşullarında eğitim kurumlarında üzerinde önemle durulması gereken konu, verilen eğitim hizmetinin kalitesidir. $\mathrm{Bu}$ bağlamda hizmet kalitesinin sağlanabilmesi insan odaklı bir düşünüşle mümkündür. $\mathrm{Bu}$ yüzden çalışma içerisinde genel olarak muhasebe eğitimi alan üniversite öğrencilerinin aldıkları eğitimin hizmet kalitesini oluşturan unsurları nasıl algıladıklarına değinilmiş ve bu doğrultuda Kafkas Üniversitesi İktisadi ve İdari Bilimler Fakültesinde bir anket çalışması gerçekleştirilmiştir. Şüphesiz eğitim hizmeti sunan kişilerin ana tüketici grubu o eğitimi almak isteyen öğrencilerdir. Hizmette kalite anlayışı, tüketici memnuniyetini kalıcı hale getirmek ve bu memnuniyetin sürdürülebilir olmasını sağlamaya çalışmak yönünde oluşturulmuştur. Dolayısıyla bu öğrencilerden kalite unsurlarının nelerden oluştuğu ve bu durumun içerisine dahil oldukları fakülteyi nasıl etkilediği hakkında bilgi almak önem kazanmaktadır. Bu kapsamda Kafkas Üniversitesi İktisadi ve İdari Bilimler Fakültesinde muhasebe eğitimi almış 122 öğrenciye anket uygulaması yapılmıştır. Araştırma grubuna işletme, iktisat ve siyaset bilimi ve kamu yönetimi bölümünde okuyan dördüncü sınıf öğrencileri dahil edilmiştir. Çalışma içerisinde hizmet kalitesinin beş alt boyutu olan; muhasebe eğitimi, müşteri odaklılık, saygı, fiziksel koşullar ve güvenlik aynı zamanda organizasyon becerisi ve ulaşım unsurları incelenmiştir. Öğrencilerin demografik özelliklerine göre her bir hizmet alt boyutu incelenerek faktör analizi yapılmıştır. Buna göre katılan öğrencilerin cinsiyet ve okudukları bölüm itibariyle anlamlı bir farklılık göze çarparken yaş gruplarına göre anlamlı bir farklılığa rastlanmamıştır.

Anahtar Kelimeler: Hizmet, Hizmet Kalitesi, Muhasebe Eğitimi. 


\section{Giriş}

Son zamanlarda hizmet sektörü ulaşım, eğitim, iletişim ve finansal hizmetler gibi birçok alt sektörden oluşan bir kavram haline gelmiştir. Özellikle küreselleşme, zorlu rekabet şartlarında pazarda var olabilmeleri ve büyüyebilmeleri için eğitim kurumlarını her geçen gün kaliteli hizmet sunmaya doğru yönlendirmektedir. Buradan hareketle, bulunduğu sektör içerisinde değer ve kalite oluşturmak için çalışan eğitim kurumları, eğitim camiası içerisinde var olmayı ve sürdürülebilir rekabeti garanti altına alabilecektir. Bu açıdan öğrencilerin aldıkları eğitimin kalite algısının nasıl ölçüldüğü ve öğrencilerin tercih yaparken dikkat ettiği özellikler eğitimciler açısından önemli bir konu olmaktadır.

Kalite kavramı, insanoğlunun bütün dönemlerinde vazgeçilmez bir unsur olup; memnuniyeti sağlamak hizmet işletmelerinin birincil hedeflerindendir. Eğitim kurumları da diğer kamu kurumları gibi hizmet kalitesine önem vermektedir. Özellikle yükseköğretim kurumlarındaki birçok faaliyet ve program eğitim-öğretim kalitesinin artıracak bilginin üretimi ve yaygınlaşması için oluşturulmaktadır.

$\mathrm{Bu}$ bağlamda önce kalite ve hizmet kalitesi kavramlarına değinilmiş daha sonra hizmet kalitesinin ölçümü ile ilgili bilgiler verilmiştir. Özellikle muhasebe eğitimi alan öğrencilerin hizmet kalite algısı incelendiği için muhasebe eğitiminin hizmet kalitesinin nasıl olması gerektiği ile ilgili kavramsal çerçevede kullanılmıştır. Bununla birlikte, çalışma içerisinde genel olarak öğrencilerin aldıkları hizmet bağlamında mensubu bulundukları üniversiteyi değerlendirmeleri temel amaç edinilmiş olup; yapılan analiz sonucunda hizmet kalitesini değerlendiren beş alt faktöre ulaşılmıştır. Bu faktörlerden biri her bölümde temel ders olarak görülen muhasebe eğitimi ile ilgili olmuş diğer faktörler ise; müşteri odaklılık, saygı, fiziksel koşullar ve güven, organizasyon becerisi ve ulaşım şeklinde sıralanmıştır. Çalışma kapsamında öğrencilerin hizmet kalitesi değerlendirmeleri hangi hizmet kalitesi boyutlarına önem verdikleri sunulmuştur.

\section{Kalite Kavramı}

Bütün örgütleri yönetenler, şiddetli rekabet ortamında kalıcı olmayı temel amaç ve hedefleri arasında kabul etmektedir. Örgüt rekabet ortamında sadece kendi standartlarıyla ortaya koyduğu hizmetlerin alıcısı olmadığını ve bu durumun verimsizliğe neden olduğunu görmektedir. $\mathrm{Bu}$ nedenle örgütler kalıcı olmak amacıyla geleneksel yaklaşımlarından kaçınarak "kalite" ve "verimlilik" kavramlarını stratejik planlarına yerleştirmektedirler. Bu anlayışla, örgütlerin hizmet bekleyen herkesi memnun etmek için onların beklentilerini önceden tespit ederek buna uygun hizmeti en kaliteli ve verimli bir biçimde sunmaktadırlar. Bu çerçevede kalite; hizmet üretimi için kişilerin beklentilerini yanıtlama ve memnun etme düzeyi olarak ifade edilmektedir (Şahin, 2009: 106).

Aslında kalite için örgütteki geliştirme faaliyetlerinin çeşitli süreçlerinin bir araya getirilmesi tanımı da yapılmaktadır. Uygulanan bir sürecin neden var olduğunu anlayabilmek o süreci geliştirmenin ilk adımıdır. Genellikle bir örgütte süreç devam ederken amacının ne olduğu unutularak süreç kendi haline bırakılmaktadır. Bu yüzden bütün süreçlerin kişilerin ihtiyaçlarını karşılamak için var olduğunu unutmadan süreci devam ettirmeli, her bir sürecin hangi ihtiyaç ve beklentiyi karşıladığını belirlemek zorunludur (Özdemir, 2002: 254).

Literatürde yapılan çalışmalar incelendiğinde memnuniyet ve kalite kavramlarının birlikte kullanıldığı görülmektedir. Ancak memnuniyet kavramı; kişinin ürün ya da hizmete karşı olan tutum düzeyi ve tüketime özgü bir onaylama olarak düşünülebilecek bir duygusal tepki şeklinde tanımlanmaktadır. Kalite ise kişinin aldığı hizmetin üstünlüğünü tasdikleyen bir yarg1 veya tutum olarak tanımlanmaktadır (Sönmez, 2018: 160). 


\section{Hizmet Kavramı}

Günümüz dünyasının küreselleşmesi ekonominin ve sanayileşmenin gelişmesini tetiklerken buna paralel şekilde hizmetlerin bu gelişimdeki payı giderek artmaktadır. Bunun sebebi, öncelikle hizmet sektörünün bir gelişmişlik düzeyi göstergesi haline gelmesi ve teknolojik yeniliklerin çok farklı hizmet türlerini oluşturmasıdır. Özellikle sağlık, finansman, eğitim ve hukuk gibi alanlarda ortaya çıkan değişim süreci, bu alanlarla ilgili olan hizmet türlerinin ve örgütlerinin çoğalmasına sebep olmuştur (Okumuş ve Duygun, 2008: 18).

Aslında hizmet sektörünün incelenmeye değer olan bir sektör olduğunun anlaş1lması yeni bir durumdur. Hizmet endüstrisi için kullanılan kavramlar ilk defa 1941'de ortaya atılmıştır. O y1llarda hizmet; "insan ve makineler tarafindan insan gayretiyle üretilen ve tüketicilere doğrudan fayda sağlayan ve fiziksel olmayan ürünler"dir. Hizmetler, pazar ortamındaki iki taraf arasında gerçekleşen bir değer mübadelesi sonucu ortaya çıkan ekonomik faaliyet olarak da açılanabilmektedir (Koç, 2017: 21). Bununla birlikte uygulamada hizmet, tüketiciye sadece ürün veya hizmet sağlamak yerine ürün ve hizmeti farklı dozlarda bir araya getiren bir bileşim olarak sunulmaktadır. Günümüzde örgütlerin hemen hemen hepsi saf bir mal ya da saf bir hizmet yerine tüketicilerine mal ve hizmet karışımı sunduğunu onaylamaktadır (Okumuş ve Asil, 2007: 8).

Hizmet sunan örgütler özellikle üretim örgütlerinin uyguladığı yönetim sistemlerinden faydalanmaktadır. Ürün ve hizmetin birçok ortak noktası bulunmasına rağmen hizmet unsuru büyük oranda tüketici katılımı ile meydana gelmektedir. Sistemli bir hizmet ve hizmet kalitesi sunabilmek için örgütler büyük çaba harcamakta ve değişik stratejiler oluşturmak zorundadırlar. Artık örgütler, sundukları hizmetin üstünlügü ve kalitesi ile sürdürülebilir olabileceklerinin farkında olmaya başlamışlardır (Ertuğrul ve Sarı, 2019: 24-25).

\subsection{Hizmet Kalitesi Kavramı}

Hizmet kalitesi kavramı hem hizmeti sağlayan hem de hizmeti alan açısından önemlidir. $\mathrm{Bu}$ yüzden örgütler rekabet avantajını koruma konusunda hizmet kalitesinin önemini anlamaya başlamışlardır. Özellikle pazarlama, hizmet kalitesi oluşturmada ve geliştirmede dikkat çekici bir role sahiptir. Hizmet sunan bir örgütün başka bir örgütten farkı onlardan daha iyi kalitede hizmet üretebilmesi ve satabilmesidir. Yüksek kalitede hizmet sunmak tamamen tüketici beklentilerini iyi analiz edebilmek ve bu beklentiye uygun hizmet sağlamak ile mümkün olabilmektedir (Argan ve Argan, 2002: 134).

Bununla birlikte, hizmet soyut bir kavram olduğu için hizmeti alan kişilerin kalite algısını doğru ölçebilmek örgütü zorlamaktadır. Aslında hizmet kalitesini değerlendiren uzman kişi, algılanan hizmet kalitesi değerlendirmesi yapmaktadır. Bu bağlamda algılanan hizmet kalitesi "müşterinin bir ürün veya hizmetin üstünlüğü veya mükemmelliği ile ilgili genel bir yargısı" dır (Sönmez, 2018: 160).

Esas olarak hizmet örgütlerinde kalite; anlaşılması, uygulanması ve kontrolü bakımından belirsiz ve karışı bir alan olarak görülmektedir. Hizmetler soyut nesneden ziyade performans olarak sunulduğundan sürekli aynı düzeyde kaliteyi sağlayabilmek yani kaliteyi standartlaştırmak örgüt için zor bir işlemdir. Çünkü hizmet kalitesi bir üretim alanında oluşturularak tüketiciye sunulmamaktadır. Bu yüzden birçok hizmetin sunmadan önce sayılması, ölçülmesi, stoklanması, test edilmesi, onaylanması ve garanti altına alınması mümkün değildir. Daha da ötesi performanstan oluşan hizmet özellikle emek yoğun olduğundan hizmeti sunan ve alan açısından değişiklik gösterebilmektedir. Hatta birçok hizmet açısından kalite hizmetin sunulması ve ulaştırılması sırasında tüketici ve hizmet personelinin etkileşiminden oluşmaktadır (Öztürk, 2015: 180-181).

Bundan dolayı hizmet kalitesi, üzerinde araştırma yapılan konuların başında gelmektedir. Yapılan araştırmaların çoğu hizmet kalitesinin örgüt performansı ile tüketici tatmini ile ilişkili bir 
kavram olduğunu göstermektedir (Dursun ve Çerçi, 2004: 2). Ancak, tüketici yargılarının farklılığı hizmet sunan örgütlere hizmet kalitesinin ölçümünün güç olduğunu kabul ettirmektedir (Pekkaya ve Ak1ll1, 2013: 77).

\subsection{Hizmet Kalitesinin Ölçülmesi}

Mevcut hizmet kalitesinin ölçülmesi öncelikle kalite iyileştirme ve geliştirme ile başlamaktadır. Literatürde hizmet kalitesini ölçen birçok yöntem vardır, ancak bunların arasında en yaygın kullanılan SERVQUAL (Service Quality) yöntemidir (Sönmez, 2018: 160).

SERVQUAL yöntemi 1985 yılında geliştirilmiştir, bu model aynı zamanda fark analizi olarak da bilinmektedir. SERVQUAL yöntemi "onaylamama" paradigması üzerine kurulmuştur. $\mathrm{Bu}$ paradigmaya göre, tüketici beklentisi ile tüketicinin elde ettiği hizmet eşitse beklenen ile algılanan performans birbirini onaylıyor sonucu çıkmaktadır. Aksine beklenti, tüketicinin elde ettiği hizmetten fazla ise sırasıyla negatif ya da pozitif onaylamama sonucu çıkmaktadır. Bu yüzden hizmet örgütleri en azından tüketici beklentisine eşit bir hizmet sunumu ortaya koymak zorundadır (Okumuş ve Duygun, 2008: 20).

1985 'te geliştirilen yöntemde, hizmetin türüne bakılmaksızın tüketicilerin aldıkları hizmet kalitesini tanımlayan 10 farklı kriter ortaya çıkmıştır. Kriterler sırasıyla; fiziki unsurlar, güvenilirlik, duyarlılık, iletişim, tutarlılık, emniyet, yeterlilik, saygı, ulaşılabilirlik ve empatiden oluşmaktadır. Bir süre sonra kriterler; fiziki unsurlar, güvenilirlik, duyarlılık, kesinlik ve empati olmak üzere beşe düşürülmüştür (Dursun ve Çerçi, 2004: 3). Bu bağlamda tüketici beklenti ve algılarını karşılaştıran SERVQUAL yöntemi çok kullanılan ve dikkate alınan bir hizmet kalitesini ölçme yöntemidir. Modeli geliştirenler açısından, bu yöntem hizmet kalitesi ölçümü yapan örgütlerin güçlü ve zayıf yönlerini ortaya koyan bir modeldir (Savaş ve Kesmez, 2014: 4).

\subsection{Muhasebe Eğitiminin Hizmet Kalitesi}

Eğitim; bir bireyin mensubu olduğu toplumda yeteneklerini, tutumlarını ve olumlu sayılan diğer davranış şekillerini geliştirdiği uzun soluklu bir süreci ifade etmektedir. Bu süreçte birey doğal olarak eğitim aracılığıyla kişiliğini geliştirmekte, bilgi ve becerisini arttırmakta, ilgi ve yeteneklerine göre meslek edinmektedir (Erol ve Erkan, 2008: 3). Mesleki eğitim ise, bireye belirli bir mesleğin gerektiği bilgi, beceri ve tutumları kazandırmak onu çeşitli yönleri ile geliştirmeye yönelik eğitiminin tanımıdır. Muhasebe eğitimi ile kişilere muhasebe alanında sahip olmaları gereken meslek bilgisi ve ahlakı kazandırılmaktadır (Karaağaçlı, 2002: 115).

Muhasebenin ürettiği finansal bilgiler karar alma aşamasında kullanılmakta ve bu sebeple öğrencilerin muhasebe sürecini çok iyi kavraması bir gereklilik olarak ortaya çıkmaktadır. Muhasebe ilke ve kavramlarının önemi, doğru ve güvenilir finansal bilginin üretilmesi, bunların karar almaya etkileri öğrencilere verilen muhasebe eğitiminde göz önünde bulundurulması gereken noktalar olmaktadır. Güçlü ve sağlam bir muhasebe eğitimi; mesleğin gerektirdiği teknik bilgilerle birlikte muhasebe meslek ahlakının da öğrencilere kazandırılmasıyla tamamlanmaktadır. Bunlarla birlikte öğretim elemanı, öğrenci ve ders programlarının amaca aynı anda hizmet etmesi de muhasebe eğitiminin kalitesini arttırmaktadır (Zaif ve Ayanoğlu, 2007: 118).

Muhasebe; uygulama ile iç içe olan bir bilim dalı olduğundan eğitim sürecinin kalitesini arttırmak adına; temel muhasebe bilgilerinin öğrenciye sunulması esnasında bunların gerçek uygulamalarla ilişkilendirilmesi de gerekmektedir. Bu sebepledir ki muhasebe eğitiminde sektörel düzenlemelere, yasal uygulamalara da zaman zaman yer verilerek aktif bir eğitim süreci yaratılmaktadır (Kutlu ve Güner, 2007: 30).

Kaliteli ve başarılı bir muhasebe eğitimi için içinde bulunulan çağın gereklerine uygun öğrenme odaklı politikanın güdülmesi, eğitim modellerinin sürekli geliştirilmesi, uygulamaların öğrenme sürecine dahil edilmesi, Uluslararası eğitim standartlarına göre gelecekte profesyonel muhasebeci olmayı düşünen öğrenciler için staj ve yeterlilik sınavlarında başarılı olmalarını 
sağlayacak bir eğitim alt yapısın oluşturulması zorunlu hale gelmektedir (Karasioğlu ve Duman, 2011: 174). Bunun içinde öğrencilerin aldıkları eğitim hizmetini değerlendirmeleri, kalite için önem verdikleri hizmet boyutları yol gösterici olabilmektedir. Bunu anlamanın yolu da öğrencilerden gelecek geribildirimlerin dikkate alınmasından geçmektedir.

$\mathrm{Bu}$ noktada yapılan çalışmanın temel amacı genel olarak öğrencilerin aldıkları hizmet bağlamında mensubu bulundukları üniversiteyi değerlendirmeleri ve hangi hizmet boyutlarına önem verdiklerini belirlemektir. Bu noktada ortaya çıkan alt boyutlardan biri de her bölümde temel ders olarak verilen muhasebe eğitimi olmuştur.

\section{Hizmet Kalitesi ve Muhasebe Ĕgitimi Değerlendirmeleri; Kafkas Üniversitesi İktisadi ve İdari Bilimler Fakültesi Örneği}

$\mathrm{Bu}$ bölümde yapılan anket çalışmasından elde edilen bulgular ve bulguların değerlendirilmesi yer almaktadır. Demografik sorular ve ifadeler şeklinde hazırlanan anket çalışmasını; katılımcıların bizzat doldurmaları sağlanarak veri toplanmıştır. Elde edilen veriler SPSS 21 istatistik paket programı ile değerlendirilmiştir.

\subsection{Araştırmanın Amacı ve Önemi}

Yapılan araştırmanın temel amacı; genel olarak öğrencilerin aldıkları hizmet bağlamında mensubu bulundukları üniversiteyi değerlendirmeleri olup; her bölümde temel ders olarak görülen muhasebe eğitimi ile ilgili kalite değerlendirmelerini tespit etmektir. Ayrıca hizmet kalitesi değerlendirmelerinde özellikle hangi hizmet kalitesi boyutlarına önem verdikleri belirlenmeye çalışılmıştır.

$\mathrm{Bu}$ temel amacın yanı sıra ulaşılmaya çalışılan diğer amaçlar ise aşağıdaki gibidir;

- Katılımcıların demografik özelliklerini belirlemeye çalışmak,

- Katılımcıların muhasebe derslerini hizmet kalitesi açısından değerlendirmelerini tespit etmek,

- Katılımciların mensubu bulundukları üniversiteyi; müşteri odaklılık, fiziksel koşullar ve güven, saygı, organizasyon becerisi ve ulaşım faktörleri açısından değerlendirmelerini tespit etmeye çalışmaktır.

Katılımcılara yönelik bu bölgede daha önce benzer bir anketin ve araştırmanın uygulanmamış olması çalışmayı özgün ve önemli kılmaktadır.

\subsection{Araştırmanın Kapsamı ve Sınırları}

Araştırma için hazırlanan anket formu gönüllülük esasına dayanarak; muhasebe eğitimi almış olup muhasebe derslerini ve üniversitede belirli bir zaman geçirmiş olup üniversitedeki hizmet kalitesini değerlendirebilecek öğrencilerden oluşturulmuştur. Söz konusu anket formu; Okumuş ve Duygun'un (2008) "Eğitim Hizmetlerinin Pazarlanmasında Hizmet Kalitesinin Ölçümü ve Algılanan Hizmet Kalitesi ile Öğrenci Memnuniyeti Arasındaki İlişki" adlı çalışmadan faydalanılarak hazırlanmıştır.

Bilimsel çalışmaların genelinde olduğu gibi bu alan araştırmasında da çeşitli yönlerden birtakım sınırlamalar yer almaktadır. Bunlar;

- Araştırma tasarımının kesitsel nitelikte olması ve belirli bir dönemi kapsaması, araştırmanın sınırlarından birini oluşturmaktadır. Bu bağlamda zaman kavramına dayanarak, meydana gelebilecek farklılıkları açıklamaktan uzak olduğu için net sonuçların çıkarılması mümkün görünmemektedir. 
- Araştırmadan elde edilen verilerin doğruluğu ve geçerliliği; veri toplama yöntemi için kullanılan anket formunda bulunan yargı cümleleri, yargı cümlelerin özellikleri ve kullanılan ölçek ile sinırlı tutulmuştur.

- Araştırma kapsamında tetkik edilen kavramlara bağlı olarak ölçüm araçlarının her ne kadar geçerliliği ve güvenilirliği olsa da sosyal bilimler yönünden bir kesinlik oluşturamadığ için, araştırma sonuçlarının yorumlanabilmesi bakımından önem arz eden diğer bir kısıtı ortaya koymaktadir.

- Araştırmadaki veriler ve ortaya çıkan bulgular, araştırmaya katılanlar ve onların anketteki sorulara katılma düzeyleri ile sınırlı olmaktadır.

• Öğrenci sayısının azlığı araştırmanın önemli kısıtlarından birini oluşturmaktadır.

- Bu çalışmadaki tüm bilgi, konuyla ilgili varılan yargı ve değerlendirmeler, faydalanılan bilimsel kaynaklar; istatistiksel analizlerin sonuçları, araştırmacının kullandığı bilimsel kaynaklar ve analiz sonuçlarına bağlı ulaştığı yargılar ile sınırlı tutulmuştur.

\subsection{Araştırmanın Hipotezleri}

Katılımcı öğrencilerin mensubu oldukları üniversiteyi genel olarak verdiği hizmet bağlamında ve özellikle İktisadi ve İdari Bilimler Fakültesi öğrencilerinin muhasebe eğitimi hizmetini kalite açısından değerlendirmelerini tespit etmeyi amaçlayan bu alan araştırmasında, nitel araştırma yöntemlerinden tanımlayıcı araştırma modeli kullanılmıştır. Tanımlayıcı araştırma; iki değişken arasındaki ilişkiyi göstermekte ve araştırmacının belirli bir zaman dilimi içerisinde elde ettiği bilgiler ile araştırdığı konuya ışı tutmaktadır. Bu bağlamda konunun sınırlarını belirlemekte ve görüntüsünü yansitabilmektedir (Nakip, 2013: 180).

Araştırma için aşağıdaki gibi hipotezler geliştirilmiştir;

$\mathrm{H}_{1 \mathrm{a}}$ : Katılımcıların cinsiyeti ile hizmet boyutları ortalamalarına katılımları arasında anlamlı bir farklılık bulunmaktadır.

$\mathrm{H}_{0 \mathrm{a}}$ : Katılımcıların cinsiyeti ile hizmet boyutları ortalamalarına katılımları arasında anlamlı bir farklılık bulunmamaktadır.

$\mathrm{H}_{1 \mathrm{~b}}$ : Katılımcıların bölümleri ile hizmet boyutları ortalamalarına katılımları arasında anlamlı bir farklılık bulunmaktadır.

$\mathrm{H}_{0 \mathrm{~b}}$ : Katılımcıların bölümleri ile hizmet boyutları ortalamalarına katılımları arasında anlamlı bir farklılık bulunmamaktadır.

$\mathrm{H}_{1 \mathrm{c}}$ : Katılımcıların yaşları ile hizmet boyutları ortalamalarına katılımları arasında anlamlı bir farklılık bulunmaktadır.

$\mathrm{H}_{0 c}$ : Katılımcıların yaşları ile hizmet boyutları ortalamalarına katılımları arasında anlamlı bir farklılık bulunmamaktadır.

\subsection{Araştırmanın Yöntemi}

Bilimsel çalışma sürecinde izlenilen yöntem, araştırmada elde edilen bulguların ve ulaşılan sonuçların anlamlı ve etkin bir biçimde ortaya konulabilmesi bakımından önemli görülmektedir. Dolayısıyla ilgili çalışmanın bu başlığı altında; araştırmanın ana kütlesi, bu ana kütleden yapılan örneklem seçimi, veri toplama yöntemi ve aracı, anketlerin geçerliliği ve güvenilirliği ile verilerin analizinde kullanılan yöntemler hakkında bilgilere yer verilmektedir.

\subsection{Araştırmanın Anakütlesi ve Örneklemi}

Alan çalışması kapsamında bulunan bu araştırmanın ulaşılabilir anakütlesini (evren), İktisadi ve İdari Bilimler Fakültesi’nde okuyan özellikle muhasebe dersleri almış olan ve mezun 
olabilecek durumdaki öğrenciler oluşturmaktadır. Burada amaç; öğrencilerin üniversitede belirli bir zaman dilimi geçirmiş olmaları ve özellikle değişik muhasebe dersleri almış olmaları olup ankette yer alan ifadelerde muhasebe eğitimini kalite açısından değerlendirebilmelerine imkân sağlamaktır. Mezun durumda bulunan 4.sınıf öğrencilerinden anketi doldurmayı gönüllü olarak kabul eden katılımcılar anakütleyi oluşturmakta ve bu bağlamda ana kütle yaklaşık 153 kişi olmaktadır.

Araştırma için uygun bir örneklem belirlenirken; ana kütleyi iyi temsil edebilecek bir örneklem büyüklüğüne, örneklemin geçerlilik ve güvenilirlik düzeyinin yüksek olmasına, maliyete, zaman aralığına ve araştırma verilerinin analiz edilme koşullarına dikkat edilmiştir (Padem vd., 2012: 63). $\mathrm{Bu}$ bağlamda araştırma örnekleminin belirlenmesinde, olasılıklı örnekleme yöntemlerinden basit tesadüfî örnekleme yöntemi tercih edilmiştir.

Araştırmanın örneklem büyüklügünün belirlenmesinde, örneklem hesaplama programından yararlanılmış ve örneklem büyüklüğü bu doğrultuda oluşturulmuştur. Örneklem büyüklüğünü hesaplamak için; eğer ana kütle büyüklüğü biliniyorsa,

$$
\mathrm{n}=\left(\mathrm{Nt}^{\wedge} 2 \mathrm{pq}\right) /\left(\mathrm{d}^{\wedge} 2(\mathrm{~N}-1)+\mathrm{t}^{\wedge} 2 \mathrm{pq}\right)
$$

formülü kullanılır (http://www.istatistik-tezdestek.com, 20.08.2019). Örneklem hesaplama programına göre \%95 güven aralığında ulaşılması yeterli olan örneklem sayısı 110 adet olup, uygulamanın zaman, mekân ve özellikle öğrenci sayısının azlığı kısıtları olması, bazı anketlerin de değersiz çıkması sonucu 153 anketten 122 adet anket analiz etmeye değer bulunmuştur.

\subsection{Araştırmanın Veri Toplama Yöntemi ve Aracı}

$\mathrm{Bu}$ araştırmada, sosyal bilimler alanında yaygın olarak kullanılan ve birincil veri toplama yöntemlerinden biri olan anket yöntemi kullanılmıştır. Anket yöntemi ile araştırmanın hipotezlerini sınamak için seçilen temel veri toplama aracı ise öğrenciler ile yüz yüze yapılan görüşmelerde kullanılan anket formundan oluşmaktadır.

Araştırmada kullanılan anket formu, iki bölümden oluşmaktadır. Anketin birinci bölümünde, öğrencilerin demografik özelliklerine yönelik 5 soru, ikinci bölümünde ise hizmet kalitesini; muhasebe dersleri, müşteri odaklılık, saygı, fiziki durum ve güven, organizasyon becerisi ve ulaşım gibi açılardan değerlendiren 29 yargı cümlesi bulunmaktadır.

Anket formunda aralık düzeyinde ölçümlere olanak sağlayan, beşli likert tipi ölçek kullanılmıştır. Çünkü beşli likert tipi derecelemeli ölçeğin, sosyal bilimler sahasında geniş bir kullanım alanı olduğu bilinmektedir. Ayrıca bu ölçek daha fazla, kişilerin eğilim ve tutumunu ölçmek için kullanılmaktadır (Büyüköztürk, 2010: 4). Dolayısıyla bu ölçek ile araştırmacı; katılımciların anket formunda bulunan yargı cümlelerine karşı ne derecede eğilim ve tutum gösterdiğini ölçebilmektedir.

Anket formunda bulunan 29 adet yargı cümlesine verilen yanıtların katılma dereceleri; (1) "Kesinlikle Katılmıyorum", (2) "Katılmıyorum", (3) "Kararsızım", (4) "Katıliyorum", (5) "Kesinlikle Katılıyorum" üzerinden değerlendirme yapılmıştır.

\subsection{Anketlerin Geçerlilik ve Güvenilirliği}

Araştırma için geçerlilik; bir ölçme aracının amacına uygun, doğru ve yeterli düzeyde yanıtlar alabilme derecesini göstermektedir. Yani bir anket formunun neyi ölçtüğünün ve neyi ne derecede iyi ifade ettiğinin göstergesi, geçerlilik kavramını açıklamaktadır. Bu kavram içerik, yapı ve kapsam geçerliliği olarak üç çeşit geçerlilikten oluşmaktadır (Padem vd., 2012: 63). Bu araştırmada kullanılan anket formunun geçerliliğini sağlamak için bu konuda uzman birçok akademisyen, anket sorularının uygulanabileceği noktasında olumlu görüşünü bildirmiştir.

Ölçme aracı olarak bir anket formunda bulunması gereken önemli bir özellik ise anketteki soruların güvenilir olmasıdır. Çünkü güvenilirlik; bir anket formunda bulunan yargıların 
birbirleriyle olan tutarlılığını ve kullanılan ölçeğin ilgilenilen sorunu ne derece yansıttığını ifade etmektedir. Dolayısıyla Cronbach's Alpha katsayısı 0 ile 1 arasında bir değer alıp, kullanılan ölçeğin güvenilirliği; $0.00 \leq \alpha<0.40$ aralığında ise ölçeğin güvenilir olmadığg, $0.40 \leq \alpha<0.60$ aralığında ise ölçeğin güvenilirliğin düşük olduğu, $0.60 \leq \alpha<0.80$ aralığında ise ölçeğin oldukça güvenilir olduğu, $0.80 \leq \alpha<1.00$ aralığında ise ölçeğin yüksek derecede güvenilir olduğu yönünde yorumlanmaktadır (Kalaycı, 2006: 403-405).

Bu bağlamda anket verilerinin içsel tutarlılığını ölçmek için yapılan güvenilirlik analizinde, Cronbach's Alpha katsayısı testi uygulanmıştır. Araştırma için Cronbach's Alpha katsayısı 0,94 olarak tespit edilmiş olup, bu katsayının $0.80 \leq \alpha<1.00$ aralığında yer alması ölçeğin oldukça güvenilir olduğu, bu bağlamda ulaşılan araştırma bulgularının da güvenilirlik düzeyinin yüksek olacağı yargısına varılmaktadır.

\subsection{Analiz Yöntemi}

Anket sonucunda elde edilen verilerin analiz edilmesi için SPSS 21 (Statistical Package for Social Sciences) istatistik paket programı kullanılmıştır. Hipotezlerin test edilmesinde, parametrik mi ya da parametrik olmayan (non-parametrik) testlerin mi kullanılacağını belirleyebilmek için verilerin, normal bir dağılım gösterip göstermediği incelenmiştir.

Normal dağılım; sürekli bir dağılım olup burada gözlemler çan biçiminde olmakta ve ortalama etrafında simetrik bir dağılım göstermektedir. Bu dağılımda birer ortalama türü olan aritmetik, mod ve medyan (ortanca) birbirine eşit olmaktadır (Nakip, 2013: 241). Nitel ve nicel değiş̧kenlerin normal bir dağılım gösterip göstermediğini test edebilmek için; $Z$ istatistiği, Kolmogorov-Smirnov (K-S) ve Shapiro-Wilks testleri kullanılmaktadır. Buna göre çarpıklık katsayısının standart hatasına bölünmesi sonucunda $Z$ istatistiğinin; $\alpha=0,05$ için 1,96 ve $\alpha=0,01$ için 2,58'den küçük çıkması durumunda, dağılımın normalden aşırı sapma göstermediği şeklinde yorumlanabilir. Eğer örneklem büyüklüğ̈̈; 50'den küçük olursa Shapiro-Wilks testi, 50'den büyük olursa Kolmogorov-Smirnov testi kullanılmaktadır. Bu iki testte $\mathrm{p}$ değerinin 0,05 'ten büyük çıkması durumunda, bu anlamlılık düzeyinde puanların normal dağılımdan aşırı sapma göstermediği şeklinde yorumlanmaktadır (Büyüköztürk, 2010: 42). Bu araştırmada örneklem büyüklüğü 50'den büyük olması nedeniyle Kolmogorov-Smirnov testi kullanılmıştır. Buna göre verilere normal dağılıma uygunluk testi yapılmış olup, sonuçlar aşağıdaki tablo ile gösterilmiştir. 
Tablo 1: Verilerin Normallik Testi Sonuçları

\begin{tabular}{|c|c|c|c|}
\hline \multirow{2}{*}{$\begin{array}{c}\text { Hizmet Kalitesi Alt Boyutları } \\
\text { Muhasebe Eğitimi }\end{array}$} & \multicolumn{3}{|c|}{$\begin{array}{l}\text { Kolmogorov- } \\
\text { Smirnov }^{\mathrm{a}}\end{array}$} \\
\hline & İstatistik & Sd. & p. \\
\hline $\begin{array}{l}\text { 1. Muhasebe eğitimi veren öğretim üyesinin ders anlatımındaki hitabet becerisinin } \\
\text { yeterli olması }\end{array}$ & ,255 & 123 & ,000 \\
\hline 2. Muhasebe eğitimi veren öğretim üyesinin alanında uzman ve bilgili olması & ,340 & 123 &, 000 \\
\hline $\begin{array}{l}\text { 3. Muhasebe eğitimi veren öğretim üyesinin ders esnasında verdikleri örneklerin } \\
\text { yeterli ve güncel olmas1 }\end{array}$ &, 310 & 123 & ,000 \\
\hline $\begin{array}{l}\text { 4. Muhasebe eğitimi kapsamında verilen derslerin öğrencilerin anlayabilecekleri } \\
\text { seviyede işlenmesi }\end{array}$ &, 260 & 123 & ,000 \\
\hline $\begin{array}{l}\text { 5. Muhasebe eğitimi veren öğretim üyesinin öğrencilerle iletişim becerisinin yeterli } \\
\text { düzeyde olması }\end{array}$ & ,291 & 123 & ,000 \\
\hline $\begin{array}{l}\text { 6. Muhasebe eğitimi kapsamındaki derslerde anlatılanların teorik düzeyinin yeterli } \\
\text { seviyede olması }\end{array}$ & ,287 & 123 &, 000 \\
\hline \multicolumn{4}{|l|}{ Müşteri Odaklılık } \\
\hline $\begin{array}{l}\text { 7. Üniversitenin öğrencilerin karşılaştıkları problemleri hızlı bir şekilde } \\
\text { çözebilmesi }\end{array}$ & ,199 & 123 & ,000 \\
\hline 8. Öğrencilerin şikâyet ve önerilerinin dikkate alınması & 171 & 123 &, 000 \\
\hline 9. Üniversitenin öğrencilerin özel istek ve &, 178 & 123 &, 000 \\
\hline $\begin{array}{l}\text { 10. Öğrencilerin ders dışındaki diğer hizmetleri beklemeden, hızlı bi } \\
\text { alabilmesi }\end{array}$ & , 168 & 123 & ,000 \\
\hline 11. Öğrencilerle ilgili kayıtların hatasız tutulması & , 196 & 123 & 000 \\
\hline \multicolumn{4}{|l|}{ Sayg } \\
\hline 12. Üniv & 257 & 123 & 000 \\
\hline 13. Ünive & ,225 & 123 & 000 \\
\hline 14. Üniversite çalışanlarının &, 176 & 123 &, 000 \\
\hline $\begin{array}{l}\text { 15. Üniversite çalışanlarının öğrencilerine gerçekleştiremeyeceği vaatlerde } \\
\text { bulunmaması }\end{array}$ & , 179 & 123 & ,000 \\
\hline \multicolumn{4}{|l|}{ Fiziksel Koşullar ve Güven } \\
\hline 16. Ünive &, 168 & 123 &, 000 \\
\hline 17. Sinif & ,228 & 123 & ,000 \\
\hline 18. Üniver & 215 & 123 & 000 \\
\hline 19. Üniversite çalışanl & ,224 & 123 &, 000 \\
\hline 20. Derslerde kullanılan eğitim materyallerinin yeterli düzeyde olmas1 &, 170 & 123 &, 000 \\
\hline 21. Öğrencilerin sınavlarda başarılı olmak için aldıkları eğitime güvenmeleri &, 182 & 123 &, 000 \\
\hline 22. Üniversitenin öğrencilerin kişisel kayıtlarında gizliliğ̈i ön planda tutmas1 & ,261 & 123 &, 000 \\
\hline \multicolumn{4}{|l|}{ Organizasyon Becerisi ve Ulaşım } \\
\hline 23. Derslerin vaktinde yapılmasi &, 232 & 123 &, 000 \\
\hline 24. Derslerin ders programına uygu & ,259 & 123 &, 000 \\
\hline 25. Öğrencilere derslere ne zaman girecekleri ile ilgili bilgilerin verilmesi & 251 & 123 &, 000 \\
\hline $\begin{array}{l}\text { 26. Eğitimde meydana gelen aksaklıklardan ve özel durumlardan öğrencilerin } \\
\text { haberdar edilmeleri }\end{array}$ & , 250 & 123 & ,000 \\
\hline $\begin{array}{l}\text { 27. Üniversite çalışanlarının eğitim hizmetleri ile ilgili gerekli bilgi ve deneyime } \\
\text { sahip olmaları }\end{array}$ & ,243 & 123 & ,000 \\
\hline 28. Üniversitenin kolay ulaşılabilir bir yerde olması & ,261 & 123 & ,000 \\
\hline 29. Üniversite kampüsü içinde ulaşımın kolay olma & ,253 & 123 &, 000 \\
\hline
\end{tabular}

Tablo 1'de verilerin normallik testi sonuçları bulunmaktadır. Kolmogorov-Smirnov test sonuçlarına göre, yargı cümlelerindeki veriler normal dağılım göstermemektedir. Çünkü test sonuçlarında yer alan anlamlılık düzeyleri her yargı cümlesi için de 0,05 değerinden küçüktür. Başka bir ifade ile $\alpha=0,05$ anlamlılık düzeyinde $\mathrm{p}=0,000<0,05$ olduğu için normal dağılmadığı görülmüştür. 
Katılımciların demografik özellikleri, betimleyici istatistiklerden frekans ve yüzde olarak açıklanmıştır. Ayrıca hizmet kalitesi değerlendirmelerinin hangi faktörlerden etkilendiğini belirlemek adına "faktör analizi" yapılmıştır. Hipotezlerin test edilmesi için de Kruskal Wallis-H testinden faydalanılmıştır.

\section{Araştırmada Elde Edilen Bulguların Analizi ve Değerlendirilmesi}

Bulguların analiz edildiği bu kısımda; ilk olarak ankete katılanların demografik özellikleri aşağıda yer alan Tablo 2 ile sunulmuştur.

Tablo 2: Öğrencilerin Demografik Özellikleri

\begin{tabular}{|l|l|l|}
\hline Cinsiyet & Frekans & Yüzde (\%) \\
\hline Kadın & 44 & 35,8 \\
\hline Erkek & 79 & 64,2 \\
\hline Yaş & Frekans & Yüzde (\%) \\
\hline 20 yaş altı & 9 & 7,3 \\
\hline $21-25$ yaş arası & 103 & 83,7 \\
\hline $26-30$ yaş arası & 10 & 8,1 \\
\hline 31 yaş ve üzeri & 1 & 0,8 \\
\hline Bölüm & Frekans & Yüzde (\%) \\
\hline İşetme & 63 & 51,2 \\
\hline İktisat & 36 & 29,3 \\
\hline Siyaset Bil. ve Kamu Yön. & 24 & 19,5 \\
\hline Mezun Olunan Lise & Frekans & Yüzde (\%) \\
\hline Fen Lisesi & 4 & 3,3 \\
\hline Anadolu Lisesi & 47 & 38,2 \\
\hline Yabancı Dil Ağırlıklı Lise & 13 & 10,6 \\
\hline Mesleki ve Teknik Lise & 21 & 17,1 \\
\hline Genel Programlı Lise & 38 & 30,9 \\
\hline Toplam & $\mathbf{1 2 3}$ & $\mathbf{1 0 0}$ \\
\hline
\end{tabular}

Demografik özelliklerin sonuçlarına bakıldığında; öğrenci cinsiyetlerinin erkek alanında $\% 64,2$ ile yüksek çıktığı görülmektedir. Ayrıca özellikle yaş gruplarının ağırlıklı olarak 21-25 arasında \%83,7 oranında toplanmakta olduğu görülmektedir. Bu topluluktan en fazla işletme bölümü okuyan kişilerin fazla olduğu ve bu kişilerin de bir önceki aşamada \%38,2 ile anadolu lisesi mezunu oldukları görülmektedir. Bu sonuçlara bakıldığında genç ve bilinçli bir topluluğun üzerinde anket uygulandığı anlaşılmaktadır.

\subsection{Faktör Analizi Sonuçları}

Araştırmada faktör analizi uygulanmıştır. Herhangi bir maddenin bir faktöre boyutlanabilmesi için ilgili faktör ile en az 0,500 yüke sahip olması yoğunluklu olarak tercih edilen bir durumdur. Bununla birlikte; 0,500 civarındaki ağırlıkların oldukça iyi kabul edildiği, 0,700'ün üzerindeki ağıllıkların ise çok iyi tanımlanmış olduğu ifade edilmektedir (Hair vd., 2010: 117). Ayrıca, bir faktörün en az 3 maddeden oluşmasına (Şencan, 2005: 362), binişik madde durumunda iki faktör arasındaki yük farkının en az 0,100 düzeyinde olmasına (Çokluk vd., 2012: 233) ve Varimax dönüşümü uygulanmıştır. 


\begin{tabular}{|c|c|c|c|c|c|}
\hline \multicolumn{6}{|c|}{ Tablo 3: Faktör Analizi Sonuçları } \\
\hline \multirow[b]{2}{*}{ İfadeler } & \multicolumn{5}{|c|}{ Hizmet Kalitesi Faktörler ve Faktör Yükleri } \\
\hline & $\begin{array}{l}\text { Muhasebe } \\
\text { Eğitimi }\end{array}$ & $\begin{array}{c}\text { Müşteri } \\
\text { Odaklılık }\end{array}$ & Sayg & $\begin{array}{c}\text { Fiziksel Koşullar ve } \\
\text { Güven }\end{array}$ & $\begin{array}{c}\text { Organizasyon Becerisi ve } \\
\text { Ulaşım }\end{array}$ \\
\hline 1 & 0,581 & & & & \\
\hline 2 & 0,775 & & & & \\
\hline 3 & 0,889 & & & & \\
\hline 4 & 0,921 & & & & \\
\hline 5 & 0,822 & & & & \\
\hline 6 & 0,832 & & & & \\
\hline 7 & & 0,712 & & & \\
\hline 8 & & 0,847 & & & \\
\hline 9 & & 0,910 & & & \\
\hline 10 & & 0,798 & & & \\
\hline 11 & & 0,668 & & & \\
\hline 12 & & & 0,303 & & \\
\hline 13 & & & 0,389 & & \\
\hline 14 & & & 0,868 & & \\
\hline 15 & & & 0,693 & & \\
\hline 16 & & & & 0,789 & \\
\hline 17 & & & & 0,745 & \\
\hline 18 & & & & 0,524 & \\
\hline 19 & & & & 0,331 & \\
\hline 20 & & & & 0,569 & \\
\hline 25 & & & & 0,568 & \\
\hline 26 & & & & 0,569 & \\
\hline 21 & & & & & 0,705 \\
\hline 22 & & & & & 0,735 \\
\hline 23 & & & & & 0,558 \\
\hline 24 & & & & & 0,464 \\
\hline 27 & & & & & 0,476 \\
\hline 28 & & & & & 0,691 \\
\hline 29 & & & & & 0,861 \\
\hline & & $\begin{array}{l}\text { Kaiser-Meyer- } \\
\text { Barlett Ki }\end{array}$ & $\begin{array}{l}\text { Topla } \\
\text { in (KM } \\
\text { sellik T } \\
\text { p Değe }\end{array}$ & $\begin{array}{l}66,45 \\
\text { O) Ölçek Geçerliliği } 0 \text {, } \\
\text { sti Ki Kare 2423,714 } \\
\text { i } 0,000\end{array}$ & \\
\hline
\end{tabular}

Analiz sonuçlarına göre öğrencilerin genel olarak üniversiteyi verdiği eğitim hizmeti açısından değerlendirmelerini etkileyen 5 faktör belirlenmiştir. Bu beş faktör toplam varyansın \%66,45'ini açıklamaktadır. KMO ölçek geçerliliği ise; 0.902'dir.

KMO testi için 0.50 değerinin alt sınır olması gerektiğini ve $\mathrm{KMO} \leq 0.50$ için veri kümesinin faktörlenemeyeceği bilinmektedir (Kaya, 2013: 180). Söz konusu çalışmanın KMO değeri istenen düzeydedir.

Birinci faktör "muhasebe eğitimi" şeklinde adlandırılmış olup özellikle muhasebe eğitim hizmetini değerlendirmeyi amaçlayan altı ifadeden oluşmaktadır. Bu faktör toplam varyansın \%40,31'ini açıklamaktadır. İkinci faktör "müşteri odaklılık" şeklinde adlandırılmış olup; beş ifadeden oluşmakta ve toplam varyansın \%10,56'sını açılamaktadır. Üçüncü faktör; "saygı" olarak adlandırılmış olup dört ifadeden oluşmakta ve toplam varyansın \%6,29' unu açıklamaktadır. Dördüncü faktör "fiziksel koşullar ve güven" şeklinde adlandırılmış, bu anlamda yedi ifadeden oluşmakta ve toplam varyansın \%4,91'ini açıklamaktadır. Beşinci ve son faktör ise "organizasyon 
becerisi ve ulaşım" olarak adlandırılmakta ve yedi ifadeden oluşmaktadır. Toplam varyansın \%4,37'sini açılamaktadır. Analiz sonucunda faktör yüklerinin olumluya yakın çıkması önemlidir.

\subsection{Hipotezlerin Test Edilmesi}

Araştırmada veriler normal (simetrik) dağılım göstermedikleri için, parametrik olmayan testlerden Kruskal Wallis-H testinin kullanılması uygun görülmüştür. Kruskal Wallis-H testi, parametrik olmayan testlerden tek yönlü varyans analizi yöntemidir. K bağımsız örneğin benzer ortanca değerli toplamların rastgele örnekleri olup olmadığını test etmekte kullanılmaktadır (Çolak, 2014: 50). Dolayısıyla bu analiz, ilişkisiz iki veya daha çok örneklem ortalamasının birbirinden anlamlı farklılık gösterip göstermediğini test etmekte uygulanmaktadır (Büyüköztürk, 2010: 158).

Ayrıca hipotezlerin test edilmesinde kullanılan Kruskal Wallis-H testi sonucuna göre; hipotezlerde belirtilen yargılara katılma düzeyinin gruplar arasında anlamlı bir şekilde farklılaşması durumunda, bu anlamlı farkın kaynağını bulabilmek ve hangi gruplar arasında farklılık olduğunu tespit edebilmek için non-parametrik testlerden Mann Whitney U testi de uygulanmıştır. Mann Whitney $U$ testi, iki ilişkisiz örneklemden elde edilen puanların birbirinden anlamlı bir şekilde farklılık gösterip göstermediğini test etmek için kullanılmaktadır. Yani bu test, iki ilişkisiz grubun ilgilenilen değişken bakımından evrende benzer bir dağılıma sahip olup olmadığını test etmektedir. Dolayısıyla bu testte bağımlı değişkenin en az sıralama ölçeğinde, gözlemlerin ise birbirinden bağımsız olmasını ifade etmektedir (Büyüköztürk, 2010: 155).

$\mathrm{H}_{1 \mathrm{a}}$ : Katılımcıların cinsiyeti ile boyut ortalamalarına katılımları arasında anlamlı bir farklılık bulunmaktadır.

$\mathrm{H}_{0 \mathrm{a}}$ : Katılımcıların cinsiyeti ile boyut ortalamalarına katılımları arasında anlamlı bir farklılık bulunmamaktadır.

Tablo 4: Araştırmaya Katılanların Hizmet Kalitesi Alt Boyut Ortalamalarının Cinsiyete Göre Değişimi

\begin{tabular}{|c|c|c|c|c|c|c|}
\hline Hizmet Kalitesi Alt Boyut Ortalamaları & Cinsiyet & $\mathbf{N}$ & Sira Ortalamaları & $\mathbf{X}^{2}$ & Sd. & p. \\
\hline \multirow{2}{*}{ 1.Boyut Ortalaması } & Kadın & 44 & 71,02 & \multirow[t]{2}{*}{4,495} & \multirow[t]{2}{*}{1} & \multirow[t]{2}{*}{0,034} \\
\hline & Erkek & 79 & 56,97 & & & \\
\hline \multirow{2}{*}{ 2.Boyut Ortalaması } & Kadın & 44 & 64,88 & \multirow[t]{2}{*}{0,447} & \multirow[t]{2}{*}{1} & \multirow[t]{2}{*}{0,504} \\
\hline & Erkek & 79 & 60,40 & & & \\
\hline \multirow{2}{*}{ 3.Boyut Ortalaması } & Kadın & 44 & 67,44 & \multirow[t]{2}{*}{1,617} & \multirow[t]{2}{*}{1} & \multirow[t]{2}{*}{0,204} \\
\hline & Erkek & 79 & 58,97 & & & \\
\hline \multirow{2}{*}{ 4.Boyut Ortalaması } & Kadın & 44 & 68,05 & \multirow[t]{2}{*}{1,976} & \multirow[t]{2}{*}{1} & \multirow[t]{2}{*}{0,160} \\
\hline & Erkek & 79 & 58,63 & & & \\
\hline \multirow{3}{*}{ 5.Boyut Ortalaması } & Kadın & 44 & 67,13 & \multirow[t]{2}{*}{1,426} & \multirow[t]{2}{*}{1} & \multirow[t]{2}{*}{0,232} \\
\hline & Erkek & 79 & 59,15 & & & \\
\hline & Toplam & 123 & & & & \\
\hline
\end{tabular}

Tabloda görüldüğ̈̈ üzere, araştırmaya katılan öğrencilerin her bir boyut ortalamalarına katılımın cinsiyete göre değişiminden elde edilen sıra ortalamaları; her bir boyut için kadın katılımcılarda daha yüksektir. Buna göre, yargılara kadın katılımcıların katılma düzeyinin sıra ortalaması erkek katılımcılara göre daha yüksektir.

Analiz sonucuna göre $\mathrm{H}_{1 \mathrm{a}}$ hipotezi yalnızca 1. boyut olan "muhasebe eğitimi" için kabul edilmiş diğer boyutlar için kabul edilmemiştir. Çünkü katılımcıların cinsiyetine göre 1. boyutun ortalamasına katılma düzeyleri arasında $\alpha=0,05$ anlamlılık düzeyinde; $\chi^{2}(\mathrm{sd}=1, \mathrm{~N}=123)=4,495$ ve $\mathrm{P}=0,034<0,05$ olduğundan istatistikî açıdan anlamlı bir farklılık bulunmaktadır.

$\mathrm{H}_{1 \mathrm{~b}}$ : Katılımcıların bölümleri ile boyut ortalamalarına katılımları arasında anlamlı bir farklılık bulunmaktadır. 
$\mathrm{H}_{0 b}$ : Katılımcıların bölümleri ile boyut ortalamalarına katılımları arasında anlamlı bir farklilık bulunmamaktadır.

Tablo 5: Araştırmaya Katılanların Hizmet Kalitesi Alt Boyut Ortalamalarının Bölümlere Göre

Değişimi

\begin{tabular}{|c|c|c|c|c|c|c|}
\hline Hizmet Kalitesi Alt Boyut Ortalamaları & Bölüm & $\mathbf{N}$ & Sira Ortalamaları & $\mathbf{X}^{2}$ & S.d. & p. \\
\hline \multirow{3}{*}{ 1.Boyut Ortalaması } & İşletme & 63 & 61,33 & \multirow{3}{*}{0,107} & \multirow{3}{*}{2} & \multirow{3}{*}{0,948} \\
\hline & İktisat & 36 & 60,51 & & & \\
\hline & SBKY & 23 & 63,52 & & & \\
\hline \multirow{3}{*}{ 2.Boyut Ortalaması } & İşletme & 63 & 51,72 & \multirow{3}{*}{10,281} & \multirow{3}{*}{2} & \multirow{3}{*}{0,006} \\
\hline & İktisat & 36 & 69,99 & & & \\
\hline & SBKY & 23 & 75,00 & & & \\
\hline \multirow{3}{*}{ 3.Boyut Ortalaması } & İşletme & 63 & 53,40 & \multirow{3}{*}{6,996} & \multirow{3}{*}{2} & \multirow{3}{*}{0,030} \\
\hline & İktisat & 36 & 69,19 & & & \\
\hline & SBKY & 23 & 71,65 & & & \\
\hline \multirow{3}{*}{ 4.Boyut Ortalaması } & İşletme & 63 & 53,36 & \multirow{3}{*}{7,225} & \multirow{3}{*}{2} & \multirow{3}{*}{0,027} \\
\hline & İktisat & 36 & 68,19 & & & \\
\hline & SBKY & 23 & 73,33 & & & \\
\hline \multirow{4}{*}{ 5.Boyut Ortalaması } & İşletme & 63 & 60,71 & \multirow{3}{*}{0,711} & \multirow{3}{*}{2} & \multirow{3}{*}{0,701} \\
\hline & İktisat & 36 & 59,40 & & & \\
\hline & SBKY & 23 & 66,96 & & & \\
\hline & Toplam & 122 & & & & \\
\hline
\end{tabular}

Tabloda görüldüğü üzere, araştırmaya katılan öğrencilerin her bir boyut ortalamalarına katılımın öğrencilerin okudukları bölümlere göre değişiminden elde edilen sıra ortalamaları; her bir boyut için SBKY (siyaset bilimi ve kamu yönetimi) bölümünden katılan öğrencilerde daha yüksektir. Buna göre, yargılara bu bölümde okuyan öğrencilerin katılma düzeyinin sıra ortalaması diğer bölümlerde okuyan ve ankete katılan öğrencilere göre daha yüksektir.

Analiz sonucuna göre $\mathrm{H}_{1 \mathrm{~b}}$ hipotezi yalnızca 2., 3. ve 4. boyut için kabul edilmiş diğer boyutlar için kabul edilmemiştir. Çünkü katılımcıların bölümlerine göre sırasıyla her bir boyut ortalamasına katılma düzeyleri arasında $\alpha=0,05$ anlamlılık düzeyinde; 2 . boyut için $\chi^{2}(\mathrm{sd}=2$, $\mathrm{N}=123)=10,281$ ve $\mathrm{P}=0,006 ; 3$. Boyut için $\chi^{2}(\mathrm{sd}=2, \mathrm{~N}=123)=6,996$; ve $\mathrm{P}=0,030$ son olarak 5 . boyut için $\chi^{2}(\mathrm{sd}=2, \mathrm{~N}=123)=7,225$; ve $\mathrm{P}=0,027<0,05$ olduğundan istatistikî açıdan anlamlı bir farklılık bulunmaktadır.

$\mathrm{H}_{1 \mathrm{c}}$ : Katılımcıların yaşları ile hizmet boyutları ortalamalarına katılımları arasında anlamlı bir farkl11ık bulunmaktadır.

$\mathrm{H}_{0 c}$ : Katılımcıların yaşları ile hizmet boyutları ortalamalarına katılımları arasında anlamlı bir farklılık bulunmamaktadır. 
Tablo 6: Araştırmaya Katılanların Hizmet Kalitesi Alt Boyut Ortalamalarının Yaşlara Göre Değişimi

\begin{tabular}{|c|c|c|c|c|c|c|}
\hline Hizmet Kalitesi Alt Boyut Ortalamalari & Yaş Grupları & $\mathbf{N}$ & $\begin{array}{c}\text { Sira } \\
\text { Ortalamaları }\end{array}$ & $\mathbf{X}^{2}$ & S.d. & p. \\
\hline \multirow{4}{*}{ 1.Boyut Ortalamas1 } & 20 yaş altı & 9 & 63,00 & \multirow[t]{4}{*}{2,109} & \multirow[t]{4}{*}{3} & \multirow[t]{4}{*}{0,550} \\
\hline & $21-25$ yaş arası & 103 & 63,23 & & & \\
\hline & $26-30$ yaş arası & 10 & 52,35 & & & \\
\hline & 31 yaş ve üzeri & 1 & 23,00 & & & \\
\hline \multirow{4}{*}{ 2.Boyut Ortalaması } & 20 yaş altı & 9 & 78,94 & \multirow[t]{4}{*}{4,041} & \multirow[t]{4}{*}{3} & \multirow[t]{4}{*}{0,257} \\
\hline & $21-25$ yaş arası & 103 & 59,64 & & & \\
\hline & $26-30$ yaş arası & 10 & 73,55 & & & \\
\hline & 31 yaş ve üzeri & 1 & 37,00 & & & \\
\hline \multirow{4}{*}{ 3.Boyut Ortalaması } & 20 yaş altı & 9 & 85,44 & \multirow[t]{4}{*}{5,743} & \multirow[t]{4}{*}{3} & \multirow[t]{4}{*}{0,125} \\
\hline & $21-25$ yaș arası & 103 & 60,70 & & & \\
\hline & $26-30$ yas aras 1 & 10 & 58,70 & & & \\
\hline & 31 yaş ve üzeri & 1 & 17,50 & & & \\
\hline \multirow{4}{*}{ 4.Boyut Ortalaması } & 20 yaş altı & 9 & 75,56 & \multirow[t]{4}{*}{1,981} & \multirow[t]{4}{*}{3} & \multirow[t]{4}{*}{0,576} \\
\hline & $21-25$ yaş arası & 103 & 60,82 & & & \\
\hline & $26-30$ yaş aras 1 & 10 & 64,50 & & & \\
\hline & 31 yaş ve üzeri & 1 & 36,50 & & & \\
\hline \multirow{5}{*}{ 5.Boyut Ortalaması } & 20 yaş altı & 9 & 75,56 & \multirow[t]{4}{*}{1,815} & \multirow[t]{4}{*}{3} & \multirow[t]{4}{*}{0,612} \\
\hline & $21-25$ yaş arası & 103 & 61,41 & & & \\
\hline & $26-30$ yaş arası & 10 & 58,00 & & & \\
\hline & 31 yaş ve üzeri & 1 & 41,00 & & & \\
\hline & Toplam & 123 & & & & \\
\hline
\end{tabular}

Tabloda görüldüğ̈̈ üzere, araştırmaya katılan öğrencilerin her bir boyut ortalamalarına katılımın yaş gruplarına göre değişiminden elde edilen sıra ortalamaları; her bir boyut için 20 yaş altı grupta yer alan katılımcılarda daha yüksektir. Buna göre, yargılara bu yaş grubundaki öğrencilerin katılma düzeyinin sıra ortalaması diğer katılımcılara göre daha yüksektir.

Analiz sonucuna göre $\mathrm{H}_{1 \mathrm{c}}$ hipotezi tüm boyutlar için kabul edilmemiştir. Çünkü katılımcıların yaş gruplarına göre sırasıyla her bir boyut ortalamasına katılma düzeyleri arasında $\alpha=$ 0,05 anlaml1l1k düzeyinde; $\chi^{2}(\mathrm{sd}=3, \mathrm{~N}=123)=2,109$ ve $\mathrm{P}=0,550 ; \chi^{2}(\mathrm{sd}=3, \mathrm{~N}=123)=4,041$ ve $\mathrm{P}=$ 0,$257 ; \chi^{2}(\mathrm{sd}=3, \mathrm{~N}=123)=5,743$ ve $\mathrm{P}=0,125 ; \chi^{2}(\mathrm{sd}=3, \mathrm{~N}=123)=1,981$ ve $\mathrm{P}=0,576 ; \chi^{2}(\mathrm{sd}=3$, $\mathrm{N}=123)=1,815$ ve $\mathrm{P}=612>0,05$ olduğundan istatistikî açıdan anlamlı bir farklılık bulunmamaktadır.

\section{Sonuç ve Değerlendirme}

Katılımcı öğrencilerin mensubu oldukları üniversiteyi genel olarak verdiği hizmet kalitesi ve önem verdikleri alt hizmet boyutları bağlamında değerlendirmelerini amaçlayan çalışma kapsamında elde edilen sonuçlar literatürle paralel şekilde ortaya çıkmıştır. Özellikle hizmet kalitesi kapsamında sunulan ifadelere verilen cevaplar "muhasebe eğitimi", "müşteri odakl1lık", "sayg1", "fiziksel koşullar ve güven", "organizasyon becerisi ve ulaşım" şeklinde beş alt faktörlerde yoğunluk göstermiştir. Eğitim kurumlarının hizmet kalitesi ölçme ve değerlendirme faaliyetleri ve programları düzenlerken öncelikle müşteri odaklı, yaptığı işe saygılı, fiziksel koşulları yeterli, güven sağlamış ve organizasyon becerisi yüksek olması gerektiği eğitim kurumlarının birincil hedef kitlesi olan öğrenciler tarafından belirtilmiştir.

Demografik özelliklere göre her bir hizmet kalitesi alt boyut ifadelerinin ortalaması ilişkisine bakıldığında;

- Katılımcı öğrencilerin cinsiyetine göre özellikle muhasebe eğitimi boyutuna katılımları arasında anlamlı bir fark olduğu tespit edilmiştir. Kadın katılımcıların yöneltilen ifadelere katılım 
oranları erkek katılımcılara göre daha yüksek olmuştur. Katılımcıların büyük çoğunluğunun erkek olmasına karşın kadınların bu konudaki hassasiyeti dikkat çekmektedir. Bunun anlamının kalite olgusuna kadınların daha fazla önem verdiği ve eğitim kurumlarında hizmet alan kadın topluluğun incelenen beş faktör boyutuna göre kurum alg1sı oluşturduğu söylenebilmektedir.

- Katılımcı öğrencilerin yaş gruplarına göre hizmet kalitesi alt boyut ortalamaları arasında anlamlı bir farklılık yoktur. Özellikle çıkan sonuçlar incelendiğinde 21-25 arası yaş grubunun öne çıktığı görülmesine rağmen bütün yaş gruplarının hizmette kalite kavramına karşı hassasiyet duyması önemlidir.

- Katılımcı öğrencilerin okudukları bölümlere göre müşteri odaklılık, saygı, fiziksel koşullar ve güven boyutları ifadelerine katılım oranı SBKY bölüm öğrencilerinde diğer bölümlere oranla daha yüksek olmuştur. İşletme öğrencilerinin çoğunlukta olduğu katılımcı grubunda siyaset bilimi ve kamu yönetimi öğrencilerinin daha öğrenci yönlü, titizlikle işini yapan ve işine sayg1 duyan, güvenilir ve fiziksel altyapısı yeterli eğitim kurumlarına yöneceleği sonucu ortaya çıkmıştır.

Özetle, eğitim kurumlarından eğitim hizmeti alan öğrencilerin oluşturduğu katılımcı topluluğu müşteri odaklı bir eğitim kurumu hizmet kalitesi en yüksek algılanan kurum olarak atfetmiştir. Bunu sırasıyla saygı, fiziksel koşullar ve güven ve organizasyon becerisi ve ulaşım izlemektedir. Bu çalışma sonucunda görülebileceği gibi müşteri odaklılık ve hizmetin kalite algısı arasında bir bağ bulunmaktadır. Bu bağı hedef kitleye göre yeterince kuran eğitim kurumlarının başarılı olma olasılıkları yükselmektedir. Bundan sonraki unsur olarak hizmeti veren kişilerin öğrencilere karşı saygılı olması ve hizmeti vermeye istekli olmaları, ayrıca sunamayacakları hizmetleri taahhüt etmemeleri de öğrenciler tarafından hizmetin kalite algısını farklılaştırmaktadır.

Ayrıca eğitim hizmetinin verildiği fiziksel ortamın çekici olması, hizmet vermeye uygun olması, temiz ve düzenli olması, hizmet veren kişilerin yeterli materyallerle hizmeti verebilmesi ve eğitim hizmeti organizasyonunun çok planlı ve sistematik şekilde hazırlanması da hizmet kalitesini arttıracak kriterler arasında sayılmaktadır. Böylece, eğitim hizmetini alan öğrencilerdeki memnuniyet düzeyi yükselerek o eğitim kurumunu tercih etme olasılıkları da artacaktır.

\section{Kaynakça}

Argan, M. T. \& M. Argan (2002). Sağlik Hizmetleri Pazarlamasında Kalite ve Osmangazi Üniversitesi Tıp Fakültesi Hastanesindeki Servislerde Yatan Hastalara Yönelik Bir Araştırma. 7. Ulusal Pazarlama Kongresi: 21. Yüzyllın Pazarlama Paradigması Bildiri Kitabl, 133-150.

Büyüköztürk, Ş. (2010). Sosyal Bilimler İçin Veri Analizi El Kitabı. Pegem Akademi Yayınevi.

Çokluk, Ö., G. Şekercioğlu ve Ş. Büyüköztürk (2012). Sosyal Bilimler Iç̧in Çok Değişsenli Istatistik Spss ve Lisrel Uygulamalart. Pegem Akademi.

Çolak, E. (2014). "Varyans Analizi (ANOVA) Kruskal Wallis-H Testi”, http://eczacilik.anadolu .edu.tr/bolumSayfalari/belgeler/ecz2014\%2011_20140527094539.pdf (10.10.2019).

Dursun, Y., \& Çerçi, U. M. (2004). Algılanan Sağlık Hizmeti Kalitesi, Algılanan Değer, Hasta Tatmini ve Davranışsal Niyet İlişkileri Üzerine Bir Araştırma. Erciyes Üniversitesi İktisadi ve İdari Bilimler Fakültesi Dergisi, (23), 1-16.

M., Erol \& Erkan, G. (2008). Lisans Düzeyinde Muhasebe Eğitimi Alan Öğrencilerin Başarılarını Etkileyen Faktörlerin Belirlenmesine Yönelik Biga İktisadi ve İdari Bilimler Fakültesinde Bir Araştırma, KMÜ İIBF Dergisi, 8 (14), 284-301.

Ertuğrul, İ., \& Sarı, G. Hizmet Kalitesi Ölçümünde SERVQUAL Tekniği: Bir Üniversite Uygulamas1. Organizasyon ve Yönetim Bilimleri Dergisi, 11 (1), 21-35. 
Hair, J. F. Jr., W. C., Black, B. J. Babin, ve R. E. Anderson, (2010). Multivariate Data Analysis (7th Ed.). Upper Saddle River: Prentice Hall.

Kalayc1, Ş. (2006). SPSS Uygulamalı Çok Değişkenli İstatistik Teknikleri. Asil Yayıncılık.

Karaağaçlı, M. (2002). Meslek ve Teknoloji Eğitiminde Özel Öğretim Yöntemi.Nobel Yayın Dă̆ıtım.

Karasioğlu, F., \& Duman, H. (2011). Meslek Yüksekokullarında Muhasebe Eğitimi ve Kalitesi Üzerine Bir Not. Gaziantep University Journal of Social Sciences, 10(1).

Kaya, M. F. (2013). Sürdürülebilir Kalkınmaya Yönelik Tutum Ölçeği Geliştirme Çalışması. Marmara Coğrafya Dergisi, (28), 175-193.

Koç, E. (2017). Hizmet Pazarlaması ve Yönetimi (Global ve Yerel Yaklaşım). Seçkin Yayıncılık.

Kutlu, H. A.\& M. Güner (2007). Türkiye Muhasebe Standartlarındaki Gelişmelerin Eğitim ve Uygulama Açısından İrdelenmesi. XXVI. Türkiye Muhasebe Eğitimi Sempozyumu, Antalya.

Nakip, M. (2013). Pazarlama Araştırmalarına Giriş (SPSS Uygulamalı). Ankara: Seçkin Yayınevi.

Okumuş, A., \& Asil, H. (2007). Hizmet Kalitesi Algılamasının Havayolu Yolcularının Genel Memnuniyet Düzeylerine Olan Etkisinin İncelenmesi. İstanbul Üniversitesi İşletme Fakültesi Dergisi, 36 (2), 7-29.

Okumuş, A., \& Duygun, A. (2008). Eğitim Hizmetlerinin Pazarlanmasında Hizmet Kalitesinin Ölçümü ve Algılanan Hizmet Kalitesi ile Öğrenci Memnuniyeti Arasındaki İlişki. Anadolu Üniversitesi Sosyal Bilimler Dergisi, 8 (2), 17-38.

Özdemir, S. (2002). Eğitimde Toplam Kalite Yönetimi. Kirgızistan-Türkiye Manas Üniversitesi Sosyal Bilimler Dergisi, (2), 253-270.

Öztürk, S. A. (2015). Hizmet Pazarlaması (Kuram, Uygulama ve Örnekler). Ekin Yayınevi.

Padem, H., Göksu, A. ve Konaklı, Z. (2012). Araştırma Yöntemleri (SPSS Uygulamalı). IBU Publications.

Pekkaya, M., \& Akıllı, F. (2013). Hava Yolu Hizmet Kalitesinin SERVPERF-SERVQUAL Ölçeği ile Değerlendirmesi ve İstatistiksel Analizi. Ekonomik ve Sosyal Araştırmalar Dergisi, 9 (1), 75-96.

Savaş, H., \& Kesmez, A. G. (2014). Hizmet Kalitesinin SERVQUAL Modeli ile Ölçülmesi: Aile Sağlı̆̆ı Merkezleri Üzerine Bir Araştırma. Pamukkale Üniversitesi Sosyal Bilimler Enstitüsü Dergisi, (17), 1-13.

Sönmez, H. (2018) Anadolu Üniversitesi Açıköğretim Sistemi Türkiye Programları Büro Hizmetleri Kalitesinin SERVQUAL Analiziyle Ölçümü. Anadolu Üniversitesi Sosyal Bilimler Dergisi, 18(3), 159-168.

Şahin, A. E. (2009). Eğitim Fakültesinde Hizmet Kalitesinin Eğitim Fakültesi Öğrenci Memnuniyet Ölçeği (EF-ÖMÖ) ile Değerlendirilmesi. Hacettepe Üniversitesi Ĕ̈itim Fakültesi Dergisi, 37(37), 106-122.

Şencan, H. (2005). Sosyal ve Davranışsal Ölçümlerde Güvenilirlik ve Geçerlilik. Seçkin Yayıncilik.

Zaif, F. \& Ayanoğlu, Y. (2007). Muhasebe Eğitiminde Kalitenin Arttırılmasında Ders Programlarının Önemi: Türkiye'de Bir İnceleme. Gazi Üniversitesi İktisadi ve İdari Bilimler Fakültesi Dergisi, 9 (1), 115-136. 